\title{
Patronage and power
}

$\mathrm{T}$

WELFTH-CENTURy NOBLEWOMEn exerted power and influence through cultural patronage, and scholars have begun to clarify ways that noblewomen were important. Janet Nelson has stressed that, although women were excluded from the formal religious and political authority most often associated with literacy, they still participated in the culture of literacy. ${ }^{1}$ June McCash has similarly argued that noblewomen overcame socio-cultural obstacles to participate in cultural patronage in the various literary, religious, artistic and poetic fields. ${ }^{2}$ Elisabeth van Houts confirmed the importance of female patrons of historiography, and their role as repositories of family history and in the instruction of their sons, and more importantly their central role in the creation of social memory. ${ }^{3}$ Susan Groag Bell traced a tradition whereby medieval noblewomen were important as cultural ambassadors and in the literary education of their daughters. ${ }^{4}$ The importance of female patronage in providing distinctive, innovative forms of literature is an important element in Lois Huneycutt's reassessment of the cultural patronage of Queen Matilda, wife of Henry I. ${ }^{5}$ Huneycutt and McCash argue that relations between noblewomen and churchmen were one way that women could enact strategies to achieve their own objectives. Pauline Stafford emphasised the political context of late eleventh and early twelfth-century royal female patronage to argue that female patrons could manipulate the images portrayed, including the image of their male kin. ${ }^{6}$

Thus the recent historiography on medieval women and literacy stresses ways in which women participated in literary culture as a way of pursuing their own strategies. In the context of the twelfth-century evidence, the following discussion of women's participation in spiritual relationships with churchmen argues that this was an important route for male-female interaction, and that this stimulated the production of 
devotional literature written for specific women. Thus such relationships between churchmen and noblewomen were a route for indirect female influence in the context of the production of specific texts. The role of twelfth-century secular noblewomen in procuring, commissioning and selecting literature is further developed in an examination of their role as patrons of books and literature.

\section{Women and literature: letters, prayers and poems}

Women participated in personal relationships with churchmen. For example, Eva Crispin (d. 1099), who retired to the abbey of Le Bec, treated the brother of Gilbert Crispin as her spiritual son. A relationship such as this probably involved spiritual guidance and counselling as well as practical advice and support. Margaret, Queen of Scotland, adopted Lanfranc as her 'spiritual father' c. 1070-89, ${ }^{7}$ and Lanfranc wrote to her to express his joy at accepting the role. Queen Margaret had requested Lanfranc to send her some monks; in his letter he states that he was sending three, who were, in effect, on loan. The monks, he states, are 'really indispensable' in his church, and this statement, no doubt, served to flatter the queen, since he had sent her men of ability. Further, if she was willing, he wanted them returned at a later date. They were clearly to give her practical support and advice concerning her establishment of Holy Trinity, Dunfermline. ${ }^{8}$ Thus a spiritual relationship could take a very practical form. The patronage of the church was intrinsic to aristocratic culture, and royal women were often involved in patronage of not only the fabric of the buildings through grants of land and emoluments but also interior furnishings, books and relics. ${ }^{9}$ For example, Countess Judith of Flanders presented a fine crucifix to Durham and sacred relics and objects of art to the abbey of Weingarten, including a relic of the holy blood that she had inherited from her father. ${ }^{10}$ Queen Matilda, the wife of the Conqueror, gave a richly decorated chasuble to the monks of Saint-Évroul, and Adeline, the wife of Roger of Beaumont, gave them an 'alb richly ornamented with orphrey.' ${ }^{11}$ Queen Matilda, the wife of Henry I, established an Augustinian house of canons, patronised other religious institutions and made personal gifts of bronze candlesticks to Hildebart of Lavardin and Cluny. ${ }^{12}$ She provided Chartres with two bells and Westminster Abbey with liturgical garments. ${ }^{13}$

Queen Matilda received a letter and prayer composed for her by Bishop Herbert Losinga of Norwich in $1118 .{ }^{14}$ The prayer to St John is a lyrical plea for healing and health, for the saint to act as an intercessor for the forgiveness of sins and for Matilda to be given to the protection 
of the Virgin Mary. Given that Matilda died in May 1118, it is possible that the prayer was composed for her in the context of illness. The choice for the direction of this prayer is interesting, since St John was a virgin, and this is stressed within the prayer. The virgin John was a suitable intercessor with the supreme Virgin - the Virgin Mary. Herbert, when composing the prayer, would have carefully selected appropriate imagery befitting a queen. The fruit of Queen Matilda's artistic and literary connections, the letters and literature which survive, served to 'create an aura of legitimacy and prestige' in her position as queen. ${ }^{15}$ Spiritual counsel could be an important part of the relationship between leading churchmen and important political women such as the queen, or powerful countesses. The relationship between important noblewomen and clerics thus stimulated the production of letters and spiritual texts. A critical re-evaluation of these texts could begin to trace the developing discourse of twelfth-century female spirituality in the particular context of prescriptive spirituality for the recipient in her public role as queen. The cultivation of a spiritual relationship could yield political dividends and it could thus be used to influence political events of significance. ${ }^{16}$ Thus spiritual relationships were an expression of aristocratic social cohesiveness and a route whereby women could exert power.

An impressive illustration of these themes is provided by Adela of Blois, the daughter of William the Conqueror, and Matilda, who married Stephen count of Blois (d. 1102). Adela was a keen patron of the arts. As Elisabeth van Houts pointed out, she was a patron of the poet Godfrey of Rheims, who, in 1080-5, wrote to Adela praising her as a regia virgo, a royal virgin. ${ }^{17}$ Godfrey wrote that it was God's will that William had been successful at Hastings, since Adela was then born the daughter of a king instead of a duke. ${ }^{18}$ Hugh of Fleury dedicated his Historia Ecclesiastica to her. He praised her for her literacy, generosity and intelligence. ${ }^{19}$ Adela had also received the Flowers of Psalms and seven prayers selected by Anselm at her request. He also sent some prayers that he had composed for her. These were a decisive break with previous traditions in personal prayer, and marked a significant step in the development of the Anselmian revolution in the composition of texts for personal devotion. He also included advice on how to meditate. ${ }^{20}$

The relationship between Adela and Anselm was of both a political and a spiritual, personal nature. Eadmer reveals that it was Adela who played a pivotal role in resolving a dispute between her brother Henry and Anselm in 1105 at the height of the conflict between them. Eadmer informs us that she sent to Anselm to tell him that she was ill and he 
diverted to minister to her. She was appalled to hear that her brother was about to be excommunicated and arranged a meeting between Anselm and Henry at which they resolved their differences for good. ${ }^{21}$ Her illness was probably a pretext to divert Anselm to her court, where she could influence him. ${ }^{22}$ Adela was a peacemaker in the dispute between her brother and the exiled archbishop of Canterbury, and arguably she acted to care for her brother's soul in a familial context. However, the resolution of the dispute is also of political significance, and here Adela's actions assume a wider context, since she used her informal influence, which was strengthened through a spiritual relationship, to resolve a political dispute. There is a further dimension to the fact that Anselm diverted to see Adela on hearing that she was ill. Evidently his role as a spiritual adviser involved an obligation for the care of her soul to attend her in the case of serious illness to prepare Adela for death.

This network of spiritual guidance and social intercourse was normal and part of the culture of aristocratic and noble women - indeed, the women of the Conqueror's family were particularly prominent as patrons. ${ }^{23}$ Adela attracted the attention of important clergy who were keen to foster relations with her. For example, Baudri abbot of Bourgueil (1079-1130) wrote a poem of 1,367 lines for Adela which describes the furnishings and rich decorations of her hall and bedchamber. ${ }^{24}$ It used to be thought that the rich visual imagery and the detail in his descriptions were suggestive of a personal relationship between Adela and Baudri, and that he might have visited her palace. ${ }^{25}$ However, Shirley Ann Brown and Michael Herren have cast doubt on this assumption in their comparison of the Bayeux Tapestry itself with the descriptions of the tapestry which Baudri purports to have seen hanging in Adela's chamber, which historians have assumed was the Bayeux Tapestry. ${ }^{26}$ Whether or not Baudri visited Adela, the poem is significant, since it illustrates what an important abbot thought was a suitably flattering description to offer an important woman, as well as providing clues about the material culture of an aristocratic secular woman. It also illustrates the range of cultural influences in northern France, and significantly Baudri emphasised the role of Adela in the design and creation of tapestries. ${ }^{27}$ Firstly, he described a role which women of Adela's status undertook, that is, to oversee and direct the women who made cloth and designed tapestry, and, secondly, he flattered her artistic skills.

Baudri's relationship with Adela was not unique: he wrote poetry and obituaries for other women, although none of such length and detail as those to Adela. ${ }^{28} \mathrm{He}$ wrote to Adela's sister, Cecilia, a nun at Holy Trinity, Caen, as well as to a certain Agnes, a Lady Emma and

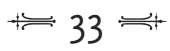


Beatrice. ${ }^{29} \mathrm{He}$ also wrote to Constance, his spiritual daughter, who had received her education at the convent of Le Ronceray in Angers, and who replied to his poetry. ${ }^{30} \mathrm{He}$ composed poetry for Muriel, who was likewise at Le Ronceray and from whom he received poetry in return. ${ }^{31}$

Anselm was therefore not alone in the way that he fostered relationships with powerful women. Eadmer reveals that on one journey Anselm was delayed and entertained by Countess Ida of Boulogne, when he 'conferred' with her. ${ }^{32}$ According to Sally Vaughn, Ida was his 'closest and most intimate confidante, student, spiritual daughter and political ally', with whom he corresponded until his death. ${ }^{33}$ Powerful women were worth cultivating: Matilda countess of Tuscany provided him with an escort whilst he was passing through her lands on his way from Rome in 1104. Anselm afterwards sent her a complete copy of his Prayers and Meditations which was made and illustrated for her at Canterbury: a step which again confirmed the shift from private meditation to public consumption of his devotional literature. Wilmart argues that the letters and prayers date from $c .1104$, and that Anselm praised Matilda for her prudence; he informed her that her people had taken him on a short safe route, and he praised her for her religious patronage and urged her to take the veil when the moment of death arrived. This is good evidence of the importance of the involvement of a secular noble woman in cross-cultural exchanges, and shows Matilda's importance in her cultural, religious and political activities. It is also worthy of note that Anselm urged her to take the veil only at the moment of death, not before. $^{34}$

Other churchmen dispensed spiritual advice to women throughout the twelfth century, for example through the medium of hagiography. The study of Vitae has been an area of increased scholarly interest, and the meaning of saints and saints' cults has likewise received considerable attention, as has women's mysticism and spirituality. ${ }^{35}$ Despite the hagiographic convention and the Christian didactic purpose of saints' lives, they are valuable sources which can be used to study aspects of noblewomen and power in twelfth-century society, although such a project has its own methodological difficulties. Indeed, Jocelyn WoganBrowne discussed three female-authored twelfth-century Vitae and showed the specific problems inherent in recovering women's experience from hagiographic sources. ${ }^{36}$ The twelfth-century Vita of Christina of Markyate has been studied for its value as a source for twelfthcentury female religious. ${ }^{37}$ Thomas Head, however, analysed the Life in terms of the socio-cultural contexts of twelfth-century developing notions of marriage. He stressed the power of Christina to seize control 
over her own life to become 'a primary actor in the drama of her own salvation'.$^{38}$ Her difficult adolescence where she was in fear of marriage is a topos typical in Vitae of female saints. ${ }^{39}$ Yet the female life cycle can be seen as paramount in defining Christina's options, since Christina became secure in her vocation only once her childbearing years were over. ${ }^{40}$ Other Vitae confirm that social and spiritual relationships were important forms of male-female interaction and collaboration. The Life of St Hugh of Lincoln by Adam of Eynsham was written as part of the campaign for Hugh's canonisation. ${ }^{41}$ It depicts a courtly political bishop attending to the spiritual needs of his flock, including, for example, 'devout matrons' and the bereaved Queen Berengaria following the death of Richard I, and adjudicating in cases of adultery. ${ }^{42}$ More interestingly, women's voices can be detected as witnesses to his sanctity. A significant number of those who testified to miracle cures were women; of twentynine individuals who are listed as having been cured of some affliction by miracles eighteen were women. ${ }^{43}$ In this respect this $2: 1$ pattern of imbalance in women : men miracle cures is a phenomenon that applies to other twelfth-century saints. ${ }^{44}$ Women's testimony and role as sources of information on the saint are therefore one way in which they could influence the shape and content of the text. Georges Whalen has shown that in Goscelin's Life of Edith statements of women's theological equality in Christ were employed where women were the majority of witnesses to allay fears about the validity of female witnesses. No such statements were required for male witnesses. ${ }^{45}$ Women were prominent as witnesses, and thus in the creation of social memory, in John of Ford's Life of Wulfric of Haslebury, a parish priest turned anchorite in rural Somerset who died in 1154. These witnesses included women from the nobility, five local anchoresses and village women. ${ }^{46}$ The Life also depicts social interaction between the anchorite and women, as well as spiritual advice and relationships. ${ }^{47}$

The dispensation of spiritual advice could be achieved through social/spiritual interaction, and also through letters. Peter of Blois wrote to the archdeacon of Picardy that his niece Alice should not be forced to become a nun, but in a later letter to her he congratulated her on her choice of vocation. ${ }^{48}$ In the mid-twelfth century Amice countess of Leicester received a letter from Gilbert Foliot. Writing c. 1163-68, he apologises for being unable to visit her, owing to his duties and obligations, and states that he ought to have written to her before. ${ }^{49}$ Gilbert Foliot was also in correspondence with her husband Earl Robert (II) of Leicester (d. 1168) in the same period, which suggests that the extant letters were sent together but were intended for each individual

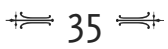


separately. ${ }^{50}$ These socially exclusive circles of friendship, cultivated through spiritual relationships, reinforced aristocratic and noble social and political cohesion. ${ }^{51}$ Noblewomen, as part of the landed élite, actively participated in such relationships.

\section{Women as patrons: the high nobility}

Noblewomen exerted power and influence through patronage. They were involved in the production and patronage of the written word not in only a personal/spiritual context, through personal letters and charters, but also through other forms of literature such as poetry, histories and literature. They were patrons for political, religious, personal and familial, educational and cultural reasons. ${ }^{52}$ This tradition of female involvement with literacy, books and book production can be seen in the Carolingian period, and continued into the late Middle Ages. ${ }^{53}$ In this context it is high-status women who are most visible, and this may well reflect the cost of books and also their access to resources. ${ }^{54} \mathrm{~A}$ striking example of a rich patron of book production is Countess Judith of Flanders, who acquired at least two illuminated gospels from Winchester, and whose library contained at least two other manuscripts possibly of Flemish origin. Her daughter-in-law, Countess Matilda of Tuscany, received a copy of Judith's book as a wedding gift in 1086, and she may have presented it to her favourite abbey. ${ }^{55}$ Judith and Matilda had royal connections, and this tradition of royal women's patronage of books continued into the twelfth century. In twelfth-century England and Normandy it is significant that women had a role in the patronage of innovative forms of literature which affected the development of secular literature. Royal women or women of high status were in the vanguard of patronising these new forms of literature.

As discussed earlier, Adela of Blois was a patron of poets, and writers were able to articulate a positive image of lay women as readers. Hugh of Fleury in the dedication of his Ecclesiastica Historia praised Adela's generosity, intelligence and literary skills, and stated that women were often capable of acquiring such capabilities. He illustrates this theme with a biblical passage where women seated at the feet of Christ understood His teaching better than Pharisees and Saducees. ${ }^{56}$ Adela's sisterin-law, Queen Matilda, commissioned the Life of her mother, Queen Margaret of Scotland. ${ }^{57}$ Queen Margaret's granddaughter, Matilda countess of Boulogne, commissioned the Vita of her maternal grandmother, Ida countess of Boulogne. ${ }^{58}$ Queen Matilda also requested that the poem 'The Voyage of St Brendan' should be translated into French. ${ }^{59}$ It is

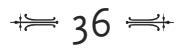


possible that Anselm was involved here, since it appears that a certain Brendan left the abbey of Bec with Gilbert Crispin in the service of Anselm. He may well have been introduced to Anglo-Norman courtly circles c. 1085. 'The Voyage of St Brendan' is a description of the life of St Brendan. Although it is not a hagiographic piece it was immensely popular, and over 120 versions survive. ${ }^{60}$ It is the earliest surviving example of a poem in octosyllabic form, and prefigured romance literature ${ }^{61}$ It is a Celtic version of the classical odyssey poem, a well worn literary theme, and thus possibly particularly popular at the AngloNorman court, given eleventh-century Norman expansion into England, Wales and Sicily as well as the recent preaching and popular response to the first Crusade. ${ }^{62}$ Thus Queen Matilda patronised a poet who was not only experimental and at the vanguard of creativity with fictional forms but who could provide the court with a cosmopolitan and exciting travel story. It was possibly part of her duty to provide courtly entertainment. ${ }^{63}$ Her cultural patronage was extensive and included the acquisition of genealogies. ${ }^{64}$ It was Matilda who asked William of Malmesbury to write The Deeds of the Kings of England. ${ }^{65}$ Henry I's second wife, Adeliza of Louvain, likewise had an appetite for new literary styles. She was a patron of Philippe de Thaon, who dedicated a bestiary to her, the oldest surviving example in the French language ${ }^{66}$ She commissioned a life of Henry I which is unfortunately now lost. The tradition of royal women's patronage continued under Eleanor of Aquitaine and her daughter by the French king Louis VII, Marie countess of Champagne, for whom Chrétien de Troyes wrote Lancelot and Chevalier de la Charette between 1177 and $1181 .{ }^{67}$ She also features holding court in Andreas Capellanus's De Amore, composed in $1183-86 .^{68}$

\section{Women as patrons: the lesser nobility}

There is evidence that secular women of the lesser nobility patronised writers and poets, actively fostered the production of books and were themselves literate. In the mid-twelfth century Constance, the wife of Ralph fitz Gilbert (of an old Lincolnshire family), was a patron of the poet Gaimar, who wrote his L'Estoire des Engleis in 1135-50. He tells us that Constance bought 'for one silver mark burnt and weighed', and frequently read 'in her chamber', a copy of the now lost Life of Henry I, which had been commissioned by Henry's second wife, Adeliza of Louvain, after his death in $1135 .{ }^{69}$ Gaimar evidently thought that the Life of Henry I, a panegyric, was dull and suggested that the author, David, should include some material about feasts, 'love and gallantry, of 
woodland sports and jokes'. ${ }^{70}$ This is interesting, since it illustrates that Constance read and reread material which Gaimar considered devoid of the positive virtues of courtly life. It also perhaps indicates a certain professional rivalry: Gaimar made an implied threat that David ought to 'amend his book' or 'I will go for him'. ${ }^{71}$ Legge, however, points out that Gaimar had included such material in his Estoire, and indeed goes so far as to suggest that the inclusion of such material was directly related to the fact that he wrote for a female patron and thus described household furnishings and included details such as the wooing of Æthelfryth by King Edgar. ${ }^{72}$ Other twelfth-century writers likewise included fables and stories. ${ }^{73}$ Yet Gaimar wrote of Æethlfryth when her reputation within England was in decline. He portrayed Æthelfryth as a romantic heroine who seduced King Edgar, and as such he 'dehistoricised' his subject. ${ }^{74} \mathrm{He}$ portrayed her in romance style and thus utilised a stereotypical view of Æthelfryth's sexual power as the cause of the downfall of King Edgar. Within this misogynistic framework she is accorded the power to choose, act and effect events. Gaimar wrote for a female lay patron whose tastes accorded with the contemporary fashion. It is hard to assess whether Gaimar shaped his material to suit the taste of a female reader and it is difficult to assess whether Constance had an influence on the content of Gaimar's Estoire. Gaimar wrote to entertain and in the romance genre, and although some of his figures are without doubt fabrications, he wrote using images and words to which his audience could relate. Indeed, John Gillingham goes so far as to suggest that Gaimar articulates an alternative and secular set of values to puritanical monastic authors. ${ }^{75}$ Elisabeth van Houts finds the issue of female patronage to be important and considers that female influence affected the tone and content of contemporary writers such as Henry of Huntingdon. ${ }^{76}$

Constance acquired a copy of Geoffrey of Monmouth's Historia Regum Britanniae and commissioned Gaimar to translate it for her into Anglo-Norman from the Latin. Gaimar states that Constance 'sent to Helmsley' for a copy of the Historia Regum. Walter Espec had a copy at his castle in Helmsley in 1153, and had asked Robert of Gloucester for a copy, and subsequently lent it to Ralph fitz Gilbert. Constance borrowed it 'Of her lord, whom she loved much'. ${ }^{77}$ The impetus for the process of translating the Historia Regum thus came from Constance, and it was she who sent for the copy to borrow. It is clear that her husband borrowed the book on her behalf but that the key initiative was hers. Both Legge and Gransden ascribe the enterprise to her husband, yet clearly it was Constance's. The important conclusion that is offered 
by this evidence points to the active involvement of noblewomen in patronage of the written word, but also illustrates that a noblewoman such as Constance had her own policy and could take her own initiatives in selecting which text to acquire. It is clear therefore that she could exercise her own choice and enact a strategy, in short utilise her power as a lay patron.

The dedications of many historical works reveal that women were important patrons of historiography, and some women, usually abbesses, composed history. ${ }^{78}$ Secular women who commissioned historical works did so as part of their role in the preservation of memoria, the commemoration of the dead. ${ }^{79}$ As such they also participated in the creation of social memory, as part of the broader process by which 1066 was remembered. ${ }^{80}$ Constance too can be considered to have had a taste for history. Her choice, Geoffrey of Monmouth, was very much in vogue in the Angevin world, and thus she was innovative in her choice of literary acquisition. With King Henry II on the throne it can have done her and her family no harm to have a poet such as Gaimar adding to her reputation as a member of a family of taste and discernment, the implicit message behind his statement that she was particularly fond of the Life of Henry II's grandfather. The alleged lack of fanciful material and anecdotes in the Life therefore reflects on Constance as courtly, serious, interested in history, and cultured. As a noblewoman in twelfth-century Lincolnshire she had an interest in literature, was perhaps literate herself, and exercised her cultural patronage with political astuteness. Yet her role may well have gone beyond that of active patron but passive consumer of the written word. Gaimar states that before he could finish the translation of the Historia Regum he had 'procured many copies' of English books and books on Latin and French grammar. He goes on to say that

If his lady had not helped him,

Never by any day could he have finished it. ${ }^{81}$

It is unlikely that this is merely idle flattery of his patron's learning. His statement goes beyond the literary topos of most writers, in which they usually avowed protestations of humility in their prologues, since most writers were only too happy to declare their industriousness if not their skill. ${ }^{82}$ Thus Gaimar may well be revealing the active hand of his patron in the translation process. Other noblewomen may also have been literate. Although clerics often bemoaned the general level of literacy in secular society, it is clear from a letter of Adam of Perseigne to the countess of Chartres that she had learned Latin. ${ }^{83}$ Some secular 
women of the nobility at least could read in a language other than the vernacular. This is important, since it shows that not all secular noblewomen were excluded from a knowledge of Latin, the language of much law and learning in the twelfth century.

Geoffrey of Monmouth was among the most fashionable contemporary writers to endure in popularity beyond the twelfth century. Over 200 copies of his works survive, over two-thirds from the Continent, and they were translated into Welsh, Old English and Anglo-Norman. He was used as an authentic and reliable source by historians in France, Normandy, including Robert of Torigny, and England. Only one of his contemporaries writing in England in the mid-twelfth century, William of Newburgh, was critical. Ambiguity best characterises the attitude to Geoffrey of Gerald of Wales, who both relied upon and doubted Geoffrey's truthfulness. ${ }^{84}$ Geoffrey's Historia Regum, whilst fictitious and of dubious methodology, is nevertheless peppered with positive images of women in power. Gransden states that Geoffrey was a 'romance writer' who was 'masquerading as a historian' and whose writings 'reflect contemporary ideas and institutions'. Geoffrey praises women rulers, shows the calamity of disputed succession and illustrates succession by inheritance. ${ }^{85}$ Julia Crick suggests that Geoffrey was 'not inventing freely, but picking the spoils of the post-Conquest degeneration of the Celtic Epic' ${ }^{86}$ This contrasts with Peter Noble's view that neither writers nor audience in England were interested in Celtic material. ${ }^{87}$ Noble also states that the idealisation of women likewise held no interest for English writers and audiences. Crick suggests that the success of Geoffrey of Monmouth's History lay in the fact that, as a fictional form, it entertained and amused society. It also had a functional role in expounding the values that Geoffrey admired. ${ }^{88}$ The depiction of women within those values is central to the unfolding of the central narrative. Geoffrey's positive message that women can and did rule successfully may in part account for his popularity with a female readership such as Constance. Geoffrey was in tune with society's values - hence his popularity. The relationship between author and patron is complex but undoubtedly authors such as Geoffrey wrote to please their patron. The reception and circulation of the Historia suggest that he was different, and the Historia's popularity is testimony to the appeal of its many images, including the portrayal of women. The political context is striking. Geoffrey's positive images of female rulership were constructed at precisely the time when such images were required by the Angevin cause. Geoffrey wrote in 1136-37, when the empress, who did not land until 1139, had yet to begin pressing her claim. The women who rule in the Historia Regum do so in specific 
contexts and under certain conditions, but are portrayed as powerful nonetheless.

Geoffrey's view of women is varied and gives an insight into the ideal roles of women in society. Powerful women usually act in a specific familial context. For example, Geoffrey creates a fictional female ruler, Marcia, and ascribes to her the creation of (Offa's) Mercian law code $^{89}$ She is the mother of the heir to the kingdom, who was under age. She ruled as a powerful widow in the stead of a minor and after her death her son took over. Thus she is situated within a family context, ruling for her son. Women in contemporary society were at the most powerful stage of the female life cycle as widows, so Geoffrey here draws on a cultural norm to reinforce his message because Marcia's situation as a widow was one with which secular society could identify. ${ }^{90}$

Happy marriages feature in Geoffrey, for example the daughter of Claudius was happily married and he ordered the town of Gloucester to celebrate the fact. ${ }^{91}$ In choosing Gloucester as the location of this happy marriage Geoffrey no doubt flattered his patron. Geoffrey shows how women could be schooled in the skills necessary to govern a kingdom in the example of Helen, who was instructed by her father in the liberal arts so that she could govern the kingdom. ${ }^{92}$ This again may well have struck a resonant note in the Gloucester household, given the political context of the association of the empress with her father, Henry I. Even so, Helen, although trained to rule, is also endowed with outstanding beauty, and fulfils her function by marrying and producing a male heir to the kingdom.

Yet Geoffrey's women could in fact be cruel and as vicious as any male character. He recites the tale of Gwendolen and Estrildis. Locrinus, one of the three sons of Brutus, the mythical founder of Britain, after defeating one of his brothers in war, reserved for himself the spoils of war, which included Estrildis, a native princess. Geoffrey provides a lyrical description of her beauty, a standard topos to praise women in all literary forms of the period, and states that Locrinus wanted to marry her. This caused concern to his followers, since he was already promised to Gwendolen, the daughter of a powerful follower. He married his betrothed, Gwendolen, but loved Estrildis, so he kept her as his mistress for seven years. Both women became pregnant by him, the legitimate wife doing her duty and producing a male heir, Estrildis, the mistress giving birth to a daughter called Habren. Locrinus then deserted Gwendolen for Estrildis. Gwendolen took to arms against her husband and joined with him in battle, in which Locrinus was killed. Gwendolen then had her rivals Estrildis and her daughter drowned in a river, which 
was named after Habren - and became known as the river Severn. ${ }^{93}$ Geoffrey may have included this local detail to please his patron in situating the story so close to the Gloucester heartland and the information may have been given to Geoffrey by oral sources. After the death of her husband Gwendolen ruled for fifteen years until her son came of age and then sceptro regni insiginivit illum contenta regione Cornubie dum reliquum vite duceret. ${ }^{94}$ Gwendolen is most powerful as a widow and rules successfully for her son until he is of age to assume power for himself.

Geoffrey of Monmouth also provides the earliest version of the story of King Lear. ${ }^{95}$ The most striking aspects of the development of this story are the values and familial context in which the daughters of Lear act. The role of the daughters in maintaining family social relations is one important aspect which contemporary society may well have endorsed, particularly the emphasis on the proper maintenance of the dignity of the father by his daughters at their court, which was expressed through the maintenance of paid retainers. When Lear has only one retainer left, owing to the refusal of his elder daughters to pay for more, he decides to fall on the mercy of his youngest daughter. She refuses to receive him at her court until he is properly dressed and with a suitable retinue and sends him away with the means to procure appropriate equipment, retainers and clothing. Clearly his impoverishment would reflect poorly on her dignity at her court. ${ }^{96}$

It is hard to measure the reception of positive images of women, but, given her acquisition of a copy of Geoffrey's Historia, it is likely that they appealed to noblewomen such as Constance. She may have been a relation of Alice de Condet, ${ }^{97}$ the patron of Sanson de Nantuil, who translated the Proverbs of Solomon into French verse for 'a distinguished and beautiful lady' in the mid-twelfth-century. He inscribed the name of his patron in his prologue. Again, it is striking that a lay noblewoman patronised new forms of literature: the Proverbs was the first moral textbook in the French language. The book was produced for educational use at home, possibly under the guidance or tutelage of his mother. ${ }^{98}$ This shows that the choice of subject matter could be at the discretion of the mother and is indicative of the possible choices that noblewomen could make in deciding the content of instructive texts for their children. ${ }^{99}$ Kindred networks such as this acted as vehicles for women's cultural patronage, and matrilineal patronage is now generally accepted as important. ${ }^{100}$

It is also noteworthy that Alice ensured that her son was taught in French. It is possible that books of hours were the most popular choice for lay women in twelfth-century Europe, and indeed women may have 
directly influenced the images that were portrayed in them. ${ }^{101}$ Aristocratic and noble women continued to procure books and manuscripts throughout the twelfth and thirteenth centuries. Matthew Paris wrote a book of verse for the countess of Winchester c. 1240. He wrote a Life of St. Edward for Eleanor of Provence, the wife of Henry III; for Isabel countess of Arundel he arranged a loan of a copy of the Life of St Thomas (c. 1250) which was destined for the countess of Cornwall. ${ }^{102}$

Noblewomen's cultural patronage of literary forms was one legitimate avenue for the exercise of power. Thus women's acquisition of books, historiography, genealogies, prayers, poems and saints' lives was an important channel of political, religious and social influence. Their relations with churchmen produced personal devotional literature. These relationships demonstrate how spiritual advice was only one sphere of male-female interaction. It was possible for women, through their oral testimony, to exert influence in shaping the reputation and literary form of the saint's life. Female patronage of literature may well have affected the popularity of texts such as Geoffrey of Monmouth, and noblewomen were in the vanguard of patronising new literary forms. Further it is possible that some noblewomen were not merely passive commissioners of such work; the examples of Alice de Condet and Constance fitz Gilbert show that some twelfth-century women of the nobility were able to read and participate in the production of literature. As such they were able to exert lasting cultural influence as well as influence in contemporary society.

\section{Notes}

1 J. L. Nelson, 'Gender and genre in women historians of the early Middle Ages', L'Historiographie médiévale en Europe (Paris, 1991), p. 150.

2 J. McCash, 'The cultural patronage of medieval women: an overview', in J. H. McCash (ed.), The Cultural Patronage of Medieval Women (Athens GA: University of Georgia Press, 1996), pp. 1-49.

3 E. M. C. van Houts, Local and Regional Chronicles (Typologie des Sources du Moyen Âge Occidental, fasc. 74, Turnhout, Belgium, 1995), pp. 40-2; eadem, Memory and Gender in Medieval Europe, 900-1200 (Basingstoke: Macmillan, 1999), pp. 137-45. Van Houts's stress on male-female collaboration confirms my view that gender was decisive in shaping both the form and content of our sources, and male-female interactions were normal and an accepted part of social relations among male clergy and secular noblewomen. Such relationships represented more than one-way maleto-female spiritual guidance, but were a route for, among others things, the exertion of female cultural and political influence.

4 S. Groag Bell, 'Medieval women book owners: arbiters of lay piety and ambassadors of culture', Signs: Journal of Women in Culture and Society, 7: 4 (1982), 742-68, repr. 
M. Erler and M. Kowaleski (eds), Women and Power in the Middle Ages (Athens GA and London: University of Georgia Press, 1988), pp. 149-87, esp. p. 179.

5 L. Huneycutt, " "Proclaiming her dignity abroad": the literary and artistic network of Matilda of Scotland, queen of England 1100-18', in McCash (ed.), Cultural Patronage of Medieval Women, pp. 155-74.

6 P. Stafford, 'The portrayal of royal women in England, mid-tenth to mid-twelfth centuries', in Parsons (ed.), Medieval Queenship, pp. 143-67, at p. 167.

7 The Letters of Lanfranc, Archbishop of Canterbury, ed. H. Clover and M. Gibson (Oxford: Clarendon Press, 1979), pp. 160-3 (no. 50). For Eva Crispin see ibid., pp. 100-3 (no. 20).

8 Ibid., p. 161 (no. 3).

9 L. Huneycutt, 'Images of queenship in the high Middle Ages', Haskins Society Journal, 1 (1989), 68-9, discusses the patronage of Matilda II, wife of Henry I, and Margaret of Scotland. For examples of the rich gifts of books made by Countess Judith of Flanders see M. Harrsen, 'The countess Judith of Flanders and the library of Weingarten Abbey', Papers of the Bibliographic Society of America, 24 pts, 1/2 (1930), 1-13. For women and books in the Middle Ages generally see Bell, 'Medieval women book owners'.

10 Judith married Tostig earl of Northumbria in 1051 and subsequently Duke Welf IV of Bavaria; she died in 1079: Harrsen, 'Countess Judith of Flanders', pp. 2-8.

11 OV, 3. 240-1.

12 Huneycutt, 'Images of queenship', p. 68.

13 Huneycutt, "'Proclaiming her dignity abroad", p. 160.

14 Herbert de Losinga bishop of Norwich, The Life, Letters, and Sermons of Bishop Herbert de Losinga (b. circ. A.D. 1050, d. 1119): The Letters (as Translated by the Editors) Being Incorporated with the Life, and the Sermons being now first Edited from a MS. in the Possession of the University of Cambridge, and Accompanied with an English Translation and Notes, ed. E. Meyrick Goulburn and H. Symonds (2 vols, Oxford and London: James Parker \& Co., 1878), I, letters no. 25, pp. 298-303, and no. 28 , pp. 303-13.

15 Huneycutt, "“Proclaiming her dignity abroad"', p. 162.

16 McCash, 'Cultural patronage', pp. 17-18; Huneycutt, "'Proclaiming her dignity abroad"', p. 161.

17 E. M. C. van Houts, 'Latin poetry and the Anglo-Norman court, 1066-1135: the Carmen de Hastingae Proelio', JMH, 15 (1989), 39-62, at pp. 47-8.

18 R. R. Bolgar, The Classical Heritage and its Beneficiaries (Cambridge: Cambridge University Press, 1954), pp. 185-6. For the debate on the recipient of this letter see K. LoPrete, 'The Anglo-Norman card of Adela of Blois', Albion, 22 (1990), 571, n. 7.

19 Hugh of Fleury positively sings her praises: Ex Historia Ecclesiastica editio prima libris IIII. digesta, ed. G. Waitz (Monumenta Germaniae Historica ... Scriptorum, 9, 1851), p. 345, lines 20-4; for a note on Hugh see A. Gransden, Historical Writing in England c. 550 to c. 1307 (London: Routledge, 1974), p. 188, n. 8. R. W. Southern, Saint Anselm and his Biographer: A Study of Monastic Life and Thought, 1059-c. 1130 (Cambridge: Cambridge University Press, 1963).

20 R. W. Southern, Saint Anselm: A Portrait in a Landscape (Cambridge: Cambridge University Press, 1990), pp. 92-3, 104. 
Eadmer, Historia Novorum in Anglia, ed. M. Rule (RS, 81, 1884), pp. 164-5; see LoPrete, 'Anglo-Norman card of Adela of Blois', p. 581, who sees this as Anselm's initiative; Southern, Saint Anselm: A Portrait in a Landscape, p. 300, however, emphasises Adela's role in effecting the meeting at Laigle between Henry and Anselm which resolved the dispute.

Eadmer, Historia Novorum, pp. 27-9; see S. N. Vaughn, The Abbey of Bec and the Anglo-Norman State, 1034-1136 (Woodbridge: Boydell, 1981).

Van Houts, 'Latin poetry and the Anglo-Norman court', pp. 45-53.

4 Les Oeuvres poétiques de Baudri de Bourgeuil (1046-1130), ed. P. Abrahams (Paris: Champion, 1926), pp. 196-231. Gransden, Historical Writing, pp. 103-4 and n. 108; P. Lauer, 'Le poème de Baudri de Bourgeuil adressé à Adèle, fille de Guillaume le Conquérant et la date de la tapisserie de Bayeux', in Mélanges d'Histoire offerts à M. Charles Bémont par ses amis et ses élèves à l’occasion de la vingt-cinquième année de son enseignement à l'École pratique des hautes études (Paris: Alcan, 1913), pp. 43-58. Les Oeuvres poétiques de Baudri de Bourgeuil, pp. 103-4.

S. A. Brown and M. W. Herren, 'The Adelae comitissae of Baudri of Bourgeuil and the Bayeux Tapestry', ANS, 16 (1994 for 1993), 55-73.

Les Oeuvres poétiques de Baudri de Bourgeuil, p. 200, line 104.

8 For his obituaries, Les Oeuvres poétiques de Baudri de Bourgeuil, no. 118 (for Elpse, a countess; three lines), no. 127 (for Osanna, countess; ten lines); no. 74 (for Benedicta, a recluse; six lines).

9 Ibid., no. 198 (to Cecilia), no. 200 (to Agnes), nos 201, 215 (to Emma), nos 202-3 (to Beatrice).

Ibid., nos 204, 238; for her reply see no. 239.

Ibid., no. 199. For personal poetry by women see P. Dronke, Women Writers of the Middle Ages: A Critical Study of Texts from Perpetua (203) to Marguerite Porete (1310) (Cambridge: Cambridge University Press, 1984), who points out that none survives from northern France or England, pp. 84-106, esp. p. 97. This conflicts with Tatlock, who thought that the above Muriel was in fact a nun at Wilton in Wiltshire, based on an early twelfth-century entry in Herman of Laon's De Miraculis to the effect that some monks on a fund-raising trip to England were shown the grave of Muriel versificatrix: J. S. P. Tatlock, 'Muriel: the earliest English poetess', Publications of the Modern Language Association of America, 48 (1933), 317-21.

Eadmer, Historia Novorum, pp. 29-30.

3 S. Vaughn, 'Anselm in Italy, 1097-1100', ANS, 16 (1994 for 1993), 245-70, at pp. 251-2. Wilmart, Auteurs spirituels et textes dévots du moyen âge latin: études d'histoire littéraire (Paris: Bloud \& Gay, 1932). Southern, Saint Anselm: A Portrait in a Landscape, pp. 111-12, 163, n. 30. This contact, although not with an Anglo-Norman woman, illustrates Anselm's perceptions.

D. Weinstein and R. M. Bell, Saints and Society: The Two Worlds of Western Christendom, 1000-1700 (Chicago and London: University of Chicago Press, 1982), sets the study of saints in a broad European framework. On pilgrims and pilgrimage see R. C. Finucane, Miracles and Pilgrims: Popular Beliefs in Medieval England (London: Dent, 1977); E. A. Petroff, Body and Soul: Essays on Medieval Women and Mysticism (New York and Oxford: Oxford University Press, 1994); on the role of gender and the body in defining in medieval religion see C. Walker Bynum, Holy Feast and Holy

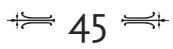


Fast: The Religious Significance of Food to Medieval Women (Berkeley CA and London: University of California Press, 1987); eadem, Fragmentation and Redemption: Essays on Gender and the Human Body in Medieval Religion (New York: Zone, 1991). F. Beer, Women and Mystical Experience in the Middle Ages (Woodbridge: Boydell, 1992), studies three medieval mystics: Hildegard of Bingen, Julian of Norwich and Mechtild of Magdeburg; V. M. Lagario, 'The medieval Continental women mystics: an introduction', in P. E. Szarmach (ed.), An Introduction to the Medieval Mystics of Europe: Fourteen Original Essays (New York: State University of New York Press, 1984), pp. 161-89, seeks a wider canvas. For twelfth-century England see S. K. Elkins, Holy Women of Twelfth-century England (Chapel Hill NC and London: University of North Carolina Press, 1988); for anchoresses see A. K. Warren, 'The nun as anchoress: England, 1100-1500', in J. A. Nichols and L. Thomas Shank (eds), Distant Echoes: Medieval Religious Women, I, Distant Echoes (Kalamazoo MI: Cistercian Publications, 1984), pp. 197-212. For the functions of a twelfth-century saint see H. Mayr-Harting, 'Functions of a twelfth-century shrine: the miracles of St Frideswide', in H. MayrHarting and R. I. Moore (eds), Studies in Medieval History presented to R. H. C. Davis (London and Ronceverte: Hambledon, 1985), pp. 193-206.

36 J. Wogan-Browne, "Clerc u lai, muïne u dame”: women and Anglo-Norman hagiography in the twelfth and thirteenth centuries', in C. M. Meale (ed.), Women and Literature in Britain, 1150-1500 (Cambridge: Cambridge University Press, 1993), pp. 61-85. Cf., with particular reference to the Ancrene Wisse, Bella Millett, 'Women in no man's land: English recluses and the development of vernacular literature in the twelfth and thirteenth centuries', in Meale (ed.), Women and Literature in Britain, pp. 87-103; Bella Millett and Jocelyn Wogan-Browne, Medieval English Prose for Women: Selections from the Katherine Group and Ancrene Wisse (Oxford: Clarendon Press, 1990).

37 Holdsworth, 'Christina of Markyate', in D. Baker (ed.), Medieval Women, Studies in Church History, Subsidia I (Oxford, 1978), pp. 185-204. The Life of Christina of Markyate: A Twelfth-century Recluse, ed. and trans. C. H. Talbot (Oxford: Clarendon Press, 1959).

38 T. Head, 'The marriages of Christina of Markyate', Viator, 21 (1990), 101.

39 Weinstein and Bell, Saints and Society, p. 48.

40 Head, 'Marriages of Christina of Markyate', p. 89, n. 51.

41 Gransden, Historical Writing, p. 313.

42 Adam of Eynsham, Magna Vita Sancti Hugonis: The Life of St Hugh of Lincoln, ed. D. L. Douie and D. H. Farmer (2 vols, 1961; corrected repr., Oxford: Clarendon Press, 1985), 1. 31-2; 2. 48; 136. See, for an exploration of the role of courtly bishops as 'political instruments', Jaeger, Origins of Courtliness, pp. 15, 255. Jaeger's main contention is that romance literature created the chivalric values of the feudal nobility. One significant problem which is not resolved in his treatment of the subject is that of the composition of the court.

43 Hugh Farmer, 'The canonization of St Hugh of Lincoln', Architectural and Archaeological Society of the County of Lincoln Report and Papers, new ser., 6: 2 (1956), 86-117, brought together papal letters and sworn testimonies made during the canonisation campaign. The role of women as sworn witnesses would be a fruitful line of enquiry for further research into the incidence of specific illnesses and, for

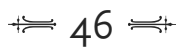


example, deformities among men and women. For example, in this sample, of the eighteen women, six, or one-third, were cured of paralysis, whereas only one man suffered paralysis; five women were cured of madness, compared with three men i.e. over 50 per cent of the men were mad, compared with 36 per cent of the women. Likewise there are illnesses which seem to apply only to men or to women, e.g. two men suffered from acute ulcerated tonsillitis (quinsy), which no women suffered, whilst four women suffered from 'dropsy' (inflammation of the body due to fluid retention). Other conditions cured include one case of pleurisy, one of female infertility, two cases of blindness (one male, one female), one boy brought back from the dead, one boy cured of dumbness and one woman cured of a hunch back. This offers a fascinating insight into conceptions of illness, and equally a social map could be drawn to discover which type of person suffered which affliction, since the social status of significant individuals is made clear, e.g. a nobleman cured of madness is listed as a nobilis. Equally the social status of sworn witnesses to the alleged cures could be studied to see whose testimony was considered important. Mayr-Harting, 'Functions of a twelfth-century shrine', p. 197. G. Whalen, 'Patronage engendered: how Goscelin allayed the concerns of nuns' discriminatory publics', in L. Smith and J. H. M. Taylor (eds), Women, The Book and the Godly: Selected Proceedings of the St Hilda's Conference, 1993 (Woodbridge: Brewer, 1995), pp. 128-9. See also van Houts, Memory and Gender, p. 51.

Wulfric of Haselbury, by John, Abbot of Ford, ed. M. Bell (Somerset Record Society, 47, 1933), pp. 38-9. A translation, unfortunately heavily abridged, can be found in The Cistercian World: Monastic Writings of the Twelfth Century, ed. P. Matarasso (London: Penguin, 1993), pp. 235-72; a new translation is in preparation by Keith Day for Cistercian Publications.

Visits from an important lady: Wulfric, chapter 41; gifts of parchment and food from women: ibid., chapters 27, 43, 104.

48 Petri Blesensis Bathoniensis Archidiaconi Opera Omnia, ed. J. A. Giles (4 vols, Oxford: I. H. Parker, 1846-47), repr. J. P. Migne, Patrologiae cursus completus, Patrologia Latina, 207 (1904), Epistle nos 54, 55; he congratulated her for accepting Christ as her spouse. The Letters and Charters of Gilbert Foliot, Abbot of Gloucester (1139-48), Bishop of Hereford (1148-63), and London (1163-87), ed. A. Morey and C. N. L. Brooke (London: Cambridge University Press, 1967), no. 195, pp. 266-7.

50 Ibid., no. 194, pp. 265-6.

51 J. Haseldine, 'Understanding the language of amicitia: the friendship circle of Peter of Celle (c. 1115-83), JMH, 20 (1994), 260, stresses the importance of such relationships, but does not address the role of women. For a general survey see C. P. McGuire, Friendship and the Community: The Monastic Experience, 350-1250 (Cistercian Studies, 95, Kalamazoo MI, 1988).

52 McCash, 'Cultural patronage', pp. 20-5; Bell, 'Medieval women book owners', pp. 163-5, 175. Nelson, 'Gender and genre', pp. 150-1. Bell, 'Medieval women book owners', p. 154. Harrsen, 'Countess Judith of Flanders', p. 9.

56 He continues: Sexus enim femineus non privatur rerum profundarum intelligentia, rerum ut sequenti lectione lucide declaribimus, solet aliquando feminis inesse magna 
mentis industriae et morum probatissimorum elegantia. Hugh of Fleury, Historia Ecclesiastica, pp. 345, lines 20-4, 350, lines 12-16.

57 For a discussion of the political significance of this Life of St Margaret of Scotland see Huneycutt, 'Images of queenship', pp. 61-72; Stafford, 'Portrayal of royal women', p. 162.

58 Duby, 'Matron and the mis-married woman', pp. 95-6.

59 Van Houts, 'Latin poetry and the Anglo-Norman court', p. 51.

60 The Anglo-Norman Voyage of St Brendan, ed. I. Short and B. Merrilees (Manchester: Manchester University Press, 1979) is the most recent translation with parallel texts. The editors state that it is unclear whether Matilda or her successor Adeliza of Louvain commissioned the work but are content to cite a date of 1106-21 for composition, see ibid., pp. 4-5.

61 Legge, Anglo-Norman Literature, pp. 9-14.

62 Which refutes Peter Noble's assertion that romance writers were not interested in Celtic material: P. S. Noble, 'Romance in England and Normandy in the twelfth century', in D. Bates and A. Curry (eds), England and Normandy in the Middle Ages (London and Rio Grande OH: Hambledon Press, 1994), pp. 69-79.

63 McCash, 'Cultural patronage', p. 23.

64 Nelson, 'Gender and genre’, p. 152.

65 Huneycutt, "'Proclaiming her dignity abroad”', pp. 157, 164.

66 Legge, Anglo-Norman Literature, pp. 22-6.

67 R. Lejeune, 'La femme dans les littératures françaises et occitanes du XI ${ }^{\mathrm{e}}$ au XIII siècle', Cahiers de la Civilisation Médiévale, 20 (1977), 207, lists the prominent women who patronised romance writers in southern France.

68 Andreas Capellanus, On Love, ed. P. G. Walsh (London: Duckworth, 1982), p. 3.

69 Adeliza married Henry in 1121 and died in 1151. Gransden, Historical Writing, p. 211; Legge, Anglo-Norman Literature, p. 28; Weiss, 'Power and weakness of women', pp. 7-23; van Houts, Memory and Gender, p. 132.

70 I cite Gaimar, Lestorie des Engles solum la Translacion Maistre Geffrei Gaimar, ed. S. Thomas Duffy and C. Trice Martin (2 vols, RS, 91, 1888-89), 2. 205, lines 6510-19. A more recent edition of the text is available in Gaimar, L'Estoire des Engleis, ed. A. Bell (Anglo-Norman Text Society, 14-16, 1960). For comments see Gransden, Historical Writing, p. 211.

71 Gaimar, Lestorie des Engles, p. 205, lines 6522, 6524.

72 Legge, Anglo-Norman Literature, p. 36.

73 Gransden, Historical Writing, p. 210.

74 Stafford, 'Portrayal of royal women', p. 156.

75 J. Gillingham, 'Kingship, chivalry and love: political and cultural values in the earliest history written in French: Geoffrey Gaimar's Estoire des Engleis', in C. Warren Hollister (ed.), Anglo-Norman Political Culture and the Twelfth-century Renaissance: Proceedings of the Borchard Conference on Anglo-Norman History, 1995 (Woodbridge: Boydell, 1997), p. 57.

76 Van Houts, Memory and Gender, p. 132.

77 Gaimar, Lestorie des Engleis, p. 203, lines 6446-57. Walter Espec's copy of the Historia Regum at Helmsley in 1153: Legge, Anglo-Norman Literature, p. 28; Gransden, Historical Writing, p. 209. 

Symposium (Woodbridge: Boydell, 1990), pp. 55-81, reprinted in A. Gransden, Legends, Traditions and History in Medieval England (London: Hambledon Press, 1992), pp. $138-9$.

83 J. Westfall Thompson, The Literacy of the Laity in the Middle Ages (Berkeley CA, 1939, repr. New York: Franklin, 1960), p. 145.

84 Gransden, Historical Writing, pp. 206, 246, 262-4.

85 Ibid., pp. 203-6.

86 J. C. Crick, The Historia Regum Britannie of Geoffrey of Monmouth, IV, Dissemination and Reception in the later Middle Ages (Cambridge: Brewer, 1991), pp. 223-4.

87 Noble, 'Romance in England and Normandy', p. 76.

88 Crick, Historia Regum, p. 224.

89 I cite Historia Regum Britannie of Geoffrey of Monmouth, I: Bern, Bürgerbibliothek MS. 568, ed. N. Wright (Cambridge: Brewer, 1985), chapters 45, 31; a convenient translation is available as Geoffrey of Monmouth, The History of the Kings of Britain, trans. L. Thorpe (Harmondsworth: Penguin, 1966).

90 Stafford, 'Portrayal of royal women', pp. 145-6.

91 Historia Regum I, chapters 69, 44.

92 Ibid. I, chapters $78,51$.

93 Ibid. I, chapters $25,15-17$.

94 Ibid. I, chapters 25, 17.

95 Gransden, Historical Writing, p. 203.

96 Historia Regum I, chapters 31, 19-22.

97 Legge, Anglo-Norman Literature, p. 38. Alice de Condet may be Alice, the sister of Ranulf II earl of Chester, who was married to Richard fitz Gilbert (d. 1136), who remarried Robert de Condet (d. 1140); for the de Condet family see The Registrum Antiquissimum of the Cathedral Church of Lincoln: Volume 1, ed. C. W. Foster (Lincoln Record Society, 27, 1931), pp. 277-95.

98 Legge, Anglo-Norman Literature, p. 41; available only in an early thirteenth-century manuscript.

99 For a wider discussion of women using texts as instructive texts see Bell, 'Medieval women book owners', pp. 160-5. Janet Nelson states this contrasts with the all-male world of the twelfth-century schools: 'Women and the word in the earlier Middle Ages', in W. J. Sheils and D. Wood (eds), Women in the Church (Studies in Church History, 27, Oxford, 1990), pp. 53-78, at pp. 76-7. Yet it may be argued that the schools were for secular clergy - Alice taught her son at home, which was a lay environment, which could reflect different roles of women to educate their children to meet the different needs of society.

100 McCash, 'Cultural patronage', p. 14.

101 Bell, 'Medieval women book owners', pp. 160-5.

102 Gransden, Historical Writing, pp. 358-9. 
Susan M. Johns - 9781526137555

Downloaded from manchesterhive.com at 04/26/2023 11:35: 09AM 